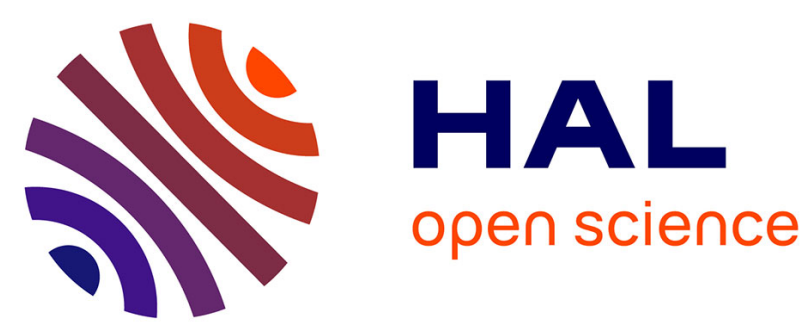

\title{
A novel chicken lung epithelial cell line: Characterization and response to low pathogenicity avian influenza virus
}

Evelyne Esnault, Claire Bonsergent, Thibaut Larcher, Bertrand Bed'Hom, Jean-François Vautherot, Bernadette Delaleu, Lydie Guigand, Denis Soubieux, Daniel Marc, Pascale Quéré

\section{To cite this version:}

Evelyne Esnault, Claire Bonsergent, Thibaut Larcher, Bertrand Bed'Hom, Jean-François Vautherot, et al.. A novel chicken lung epithelial cell line: Characterization and response to low pathogenicity avian influenza virus. Virus Research, 2011, 159 (1), pp.32-42. 10.1016/j.virusres.2011.04.022 . hal01129500

\section{HAL Id: hal-01129500 \\ https://hal.science/hal-01129500}

Submitted on 28 May 2020

HAL is a multi-disciplinary open access archive for the deposit and dissemination of scientific research documents, whether they are published or not. The documents may come from teaching and research institutions in France or abroad, or from public or private research centers.
L'archive ouverte pluridisciplinaire HAL, est destinée au dépôt et à la diffusion de documents scientifiques de niveau recherche, publiés ou non, émanant des établissements d'enseignement et de recherche français ou étrangers, des laboratoires publics ou privés. 


\title{
A novel chicken lung epithelial cell line: Characterization and response to low pathogenicity avian influenza virus
}

\author{
Evelyne Esnault ${ }^{\mathrm{a}}$, Claire Bonsergent $^{\mathrm{a}}$, Thibaut Larcher ${ }^{\mathrm{b}}$, Bertrand Bed'hom $^{\mathrm{c}}$, Jean-François Vautherot ${ }^{\mathrm{e}}$, \\ Bernadette Delaleu $^{\mathrm{d}}$, Lydie Guigand $^{\mathrm{b}}$, Denis Soubieux $^{\mathrm{e}}$, Daniel Marc ${ }^{\mathrm{e}}$, Pascale Quéré ${ }^{\mathrm{a}, *}$
}

a INRA, UR1282, Infectiologie Animale et Santé Publique, Pathologie et Immunologie Aviaires, 37380 Nouzilly, France

b INRA, UMR 703, Développement et pathologie du tissu musculaire, Ecole Nationale Vétérinaire, 44000 Nantes, France

' INRA, UMR 1313, Génétique Animale et Biologie Intégrative, 78352 Jouy-en-Josas, France

d INRA, Plateforme d'Analyses Cellulaires et Moléculaires, 37380 Nouzilly, France

e INRA, UR1282, Infectiologie Animale et Santé Publique, Biologie des Virus Aviaires, 37380 Nouzilly, France

\section{A R T I C L E I N F O}

\section{Article history:}

Received 15 December 2010

Received in revised form 22 April 2011

Accepted 23 April 2011

Available online $\mathrm{xxx}$

\section{Keywords:}

Permanent chicken lung epithelial cell line Avian influenza

\begin{abstract}
A B S T R A C T
Avian influenza virus (AIV) infections of the chicken occur via the respiratory route. Unlike ducks which are considered as a natural AIV reservoir, chickens are highly susceptible to AIV infections and do not possess the RIG-I pattern recognition receptor involved in triggering the antiviral interferon response. To study the chicken innate immune response to AIV in the respiratory tract, we established an epithelial cell line (CLEC213) from lung explants of white leghorn chickens. CLEC213 cells exhibited a polyhedral morphology and formed cohesive clusters bound through tight junctions as assessed by electron microscopy. Expression of E-cadherin but not vimentin could be detected as expected for cells of epithelial origin. In addition, CLEC213 cells showed characteristics similar to those of mammalian type II pneumocytes, including the presence of intracytoplasmic vacuoles filled with a mucopolysaccharide material, alkaline phosphatase activity, transcription of chicken lung collectins genes (CLL and SPA), and some intracytoplasmic lamellar-like bodies. CLEC213 cells showed a constitutive expression level of TLR3 and TLR4 and were responsive to stimulation with the respective agonists, poly (I:C) and LPS: between $4 \mathrm{~h}$ and $24 \mathrm{~h}$ after treatment, a strong increase in the expression of IFN- $\alpha$, IFN- $\beta$ and IL- 8 genes could be detected. Furthermore, CLEC213 cells supported efficient growth of the low pathogenicity avian influenza virus H6N2 (A/duck/France/05057a/2005) in the presence or the absence of trypsin in the culture media. At $4 \mathrm{~h}$ post-infection, the H6N2 virus induced highly levels of expression of IFN- $\alpha$ and IL-8, moderately elevated levels of LITAF, TGF- $\beta 4$ and CCL5. However, an increase of IFN- $\beta$ gene expression could not be detected in response to AIV infection. In conclusion, like mammalian type II pneumocytes, CLEC213 are able to mount a robust cytokine and chemokine immune response to microbial patterns and viral infection. We hypothesize that they could derive from lung atrial granular cells. The involvement of such type of lung epithelial cells in the respiratory tract defence of the chicken can thus be further studied.
\end{abstract}

(c) 2011 Published by Elsevier B.V.

\section{Introduction}

A number of avian respiratory pathogens, including the highly pathogenic influenza viruses (Neumann et al., 2010), are of major importance for animal and public health. Birds are prone to infections with these pathogens, and frequently the infection becomes systemic leading to fatal disease patterns. However, birds are also able to raise an immune response against these respiratory pathogens. Studies on the trachea and lung in the chicken have indeed proven that these organs are able to counter influenza virus infections through induction of immune gene transcription and

\footnotetext{
* Corresponding author. Tel.: +33 247427 912; fax: +33 247427774

E-mail address: quere@tours.inra.fr (P. Quéré).
}

leukocyte accumulation (Daviet et al., 2009; Munier et al., 2010; Reemers et al., 2009a,b).

The avian respiratory system differs in many aspects from that of mammals. It is characterized by a semi-rigid structure and the presence of air sacs. Contrary to the situation in mammals, birds lack dead-end air alveoles where exchanges between air and blood take place. Instead, bronchi and parabronchi end up in air capillaries and the air flow is continuously circulating in the same direction during inspiration and expiration, due to air sac functioning (Maina, 2002; Reese et al., 2006). This particularity also has consequences on the distribution of pathogens in the lung (Reemers et al., 2009b). Regarding the immune system, chickens have no organized lymph node stricto sensu although an organized immune system is present and functional in the bird respiratory tract. Lymphoid nodules are not present at day 1 after hatching, but have been 
46 observed in the lung mainly near the openings of the bronchus system by 8 weeks of age (Reese et al., 2006). Macrophages are generally not detected at the external surface of the airway epitheliums in birds without pathogen stimulation (Nganpiep and Maina, 2002; Reese et al., 2006). This is a major difference to the mammalian system where this type of cells belongs to the first line of non specific immune defence (Chaudhuri and Sabroe, 2008). However, macrophages are quickly recruited upon infection, presumably coming from underneath the respiratory epithelia or from the blood (Maina, 2002; Toth, 2000). Accumulation of other subpopulations of leukocytes can also be observed, demonstrating the presence of the cellular immune response in the avian respiratory tract or the lung parenchyma (Reese et al., 2006). Altogether, by comparison with what is known in mammals, our current knowledge about the functional aspects of the immune response in the bird airway tract and lung is only limited and therefore needs to be improved.

Avian influenza viruses are orthomyxoviruses that infect different types of epithelia expressing the haemagglutinin receptor. Transmission of avian influenza viruses (AIVs) can occur through various routes of infection, depending on the bird species. For example, chickens can readily be infected with AIVs via the respiratory route, where virus excretion also occurs, while ducks are predominantly infected via the digestive tract route (Jeong et al., 2009; Swayne and Slemons, 1994; van der Goot et al., 2003). A recent study has demonstrated that SA 2,3 Gal-terminated sialylglycoconjugates, acting as haemagglutinin receptors, are highly expressed in both species in trachea and intestine. These receptors are also highly expressed in the bronchi of chickens, but not of ducks (Pillai and Lee, 2010). As the first cells encountered by AIVs in the chicken, respiratory epithelia may thus be of major importance in the host defence.

In birds, the air is first circulating across turbinates and their circonvulated epithelium in the nasal cavities (Majo et al., 1996). The trachea exhibits a ciliated epithelium with goblet cells and mucus cells (Abd El Rahman et al., 2009; Henning et al., 2008; Purcell, 1971). Ciliated epithelium is also observed in primary bronchi and the initial part of secondary bronchi (Klika et al., 1998). As in mammals, the major role of the mucous and the cilia is to prevent the access of particles or pathogens to the lung parenchyma. The epithelium becomes non ciliated in parabronchi, in atria and in air capillaries (Klika et al., 1998; Scheuermann et al., 1997). Cells with a granular morphology, containing cytoplasmic lamellar bodies, have been identified mostly in the atrium scattered among squamous cells that cover infundibula and air capillaries (Scheuermann et al., 1997). A lipoproteinaceous substance, specific to birds, covers the capillary epithelium. The bird gas-blood barrier is composed of airway epithelial cells with elongated junctional dendrites and of endothelial cells, and constitutes therefore a much thinner barrier than that of mammals (Scheuermann et al., 1997; Watson et al., 2007). The granular cells could be an equivalent to mammalian type II pneumocytes, which are capable of multiplication and differentiation to type I pneumocytes to reconstitute the respiratory epithelium when damaged. However, in birds, the possible analogy of squamous cells with mammalian type I pneumocytes remains to be formally demonstrated (Scheuermann et al., 1997).

In mammals, epithelia participate actively to the host defence against respiratory pathogens. They express various pathogen recognition receptors (PRR), which can recognize specific pathogen molecular motifs. In particular they express at different levels several Toll-like receptors (TLRs), which are stimulated by viruses, bacteria and parasites (Bauer et al., 2009; Hippenstiel et al., 2006). As a consequence, epithelial cells are activated to secrete molecules such as defensins and chemokines, which in turn are responsible for recruiting a panel of immune cells and for inducing the production of a variety of cytokines. In addition to their role as a physical barrier, they are thus part of the immune system (Schleimer et al., 2007).

In birds, specific studies of the function of the different types of avian respiratory epithelia are scarce due to the lack of a standardized method to obtain primary cultures and to the quasi absence of specific cell lines. Beside a turkey turbinate cell line that was recently described (Kong et al., 2007), epithelium lining trachea explants or trachea cells in primary culture have been characterized: they are ciliated, can be infected by viruses including avian influenza viruses and can mount an immune response (Reemers et al., 2009a; Zaffuto et al., 2008). However, these cells are very difficult to maintain in vitro and quickly lose their differentiated phenotype upon repeated passage in culture. Epithelia from bird bronchi, parabronchi and air capillaries have never been isolated ex vivo, nor have permanent cell lines been established so far.

Our aim was thus to prepare and maintain in culture epithelial cells from chicken lung parenchyma and to compare their properties with those of mammalian type II pneumocytes. The latter are of major importance in the lung defence since, in addition to the production of anti-microbial lung surfactant, they are able to secrete various cytokines and chemokines during the lung pro-inflammatory response (Hippenstiel et al., 2006). Here, we describe an avian cell line named CLEC213 that exhibits a number of biochemical and morphological characteristics of pneumocytes. This cell line is permissive to the replication of a panel of low pathogenicity avian influenza viruses, to which it responds through an increased expression of several cytokine mRNAs. Our results thus suggest that chicken lung epithelial cells might participate in the immune response in a way similar to what is observed in mammals.

\section{Materials and methods}

112

113

114

115

116

117

118

119

120

121

123

124

125

126

127

128

129

130

131

132

133

134

135

\subsection{Viruses}

Low-pathogenicity avian influenza viruses A/Duck/France/05057a/2005 (H6N2) and A/Turkey/France/03295/2003 (H9N9) were a kind gift of Dr. Veronique Jestin (ANSeS, Ploufragan, France). Virus A/Mallard/Marquenterre/Z237/83 (H1N1), also referred to as "MZ", was a kind gift of Dr. Nadia Naffakh (Institut Pasteur, Paris, France). Virus A/ck/It/22A/98PD (H5N9) was a kind gift of Dr. Ilaria Capua (Istituto Zooprofilattico Sperimentale delle Venezie, Padua Italy). Viral stocks were prepared by inoculation to 10-day-old embryonated eggs. Their titers were determined on MDCK and expressed as Plaque Forming Units (PFU)/mL.

\subsection{Avian cell lines}

Chicken HD11 macrophage (Beug et al., 1979), DF1 embryo fibroblast (Himly et al., 1998) and LMH hepatocyte (Kawaguchi et al., 1987) cell lines were maintained in DMEM ( $10 \%$ fetal bovine serum [FBS, Gibco], 1\% penicillin-streptomycin [PS, Gibco]).

\subsection{Lung epithelial cell isolation}

142

143

Lungs were removed from 5 to 7 week-old SPF PA12 Leghorn chickens kept at the Experimental Infectiology Platform (PFIE, INRA, Nouzilly, France) after being thoroughly rinsed in place through injection of PBS $(20 \mathrm{~mL})$ through the lung artery. The bronchi were carefully discarded and the remaining external part of the lungs (about $1 \mathrm{~cm}$ in width) was minced in small pieces. After staying in warm $\operatorname{PBS}\left(37^{\circ} \mathrm{C}\right)$ for $2 \times 30 \mathrm{~min}$, the lung pieces were kept in MTEC medium (DMEM F12 [Dulbecco's modified Eagle medium/Nutrient F-12 Ham, Invitrogen], 4\% FBS, 1\% insulin-transferrin-selenium [ITS, Invitrogen], 7.5\% bovine serum
144

145

146

147

148

149

150

151

152

153

154

155 
Table 1

List or primers used for DNA amplification or RT-PCR.

\begin{tabular}{|c|c|c|c|}
\hline Name & Accession number & Forward & Reverse \\
\hline LEI0258 & Z83781 & cacgcagcagaacttggtaagg & agctgtgctcagtcctcagtgc \\
\hline GAB0001 & AB268588 & cattccccattaacgcactc & agagtgttggggtagccgag \\
\hline TLR3 & NM_001011691 & aacacccogctaaatatca & ccacccttcaaaatggatga \\
\hline TLR4 & NM_001030693 & tggcaggtttacaggtcaacag & gcagtcaaaaagagtgtccgtg \\
\hline IL-6 & NM_204628 & ttcgcctttcagacctacct & tggtgattttctctatccagtcc \\
\hline TGF- $\beta 4$ & M31160 & gatggacccgatgagtattg & aagaagatgctgtggctctg \\
\hline IFN- $\alpha$ & NM_205427 & aatgcttggacagcagagac & ttgtcttggaggaaggtgtg \\
\hline IFN- $\beta$ & NM_001024836 & agcaaggacaagaagcaagc & cgtgccttggtttacgaagc \\
\hline IL-1 & NM_204524 & tgggcatcaagggctacaag & ccaggcggtagaagatgaag \\
\hline LITAF & NM_204267 & ctgttctatgaccgcccagt & tcagagcatcaacgcaaaag \\
\hline IL-8 & NM_205498 & ctgcggtgccagtgcattag & agcacacctctcttccatcc \\
\hline CCL5 (RANTES) & NM_001045832 & gtgtccetctccatcctcct & tgaacacaactgctgcctgt \\
\hline CCL4 & NM_001030360 & acctcctgctgcttcaccta & ggtgcatcagttcagttcca \\
\hline SPA & NM_204606 & gtcagtggttacaaagacagc & agttcctccagtctcttcac \\
\hline cLL & DQ129667 & gctgaaagagggatatctcaagc & tcagctgttttcccactggtagc \\
\hline GAPDH & NM_204305 & gtcctctctggcaaagtccaag & ccacaacatactcagcacctgc \\
\hline
\end{tabular}

albumin [BSA, Sigma], 0.25\% human epidermal growth factor [EGF, Sigma], 1\% PS). After 2 days, the lung pieces were removed and escaping adherent cells were allowed to grow, then were trypsinized and passaged several times in MTEC at $40^{\circ} \mathrm{C}$. Cultures with rapidly dividing cells exhibiting fibroblast morphology were eliminated. A continuously growing adherent cell line (dubbed CLEC213) was obtained, trypsinized before each passage and cultured in MTEC medium.

\subsection{Histological staining}

For cytological staining, cells were trypsinized, re-suspended in PBS and deposited on pre-dried Polysin microscope slides (Menzel-Glaser, Braunschweig, Germany). In addition, to facilitate histological processing, re-suspended cells were injected into a small piece of bovine liver parenchyma. These samples were fixed in formalin, then paraffin embedded and processed to $5 \mu \mathrm{m}$ sections. In parallel, a fresh tissue sample of chicken lung was processed as an ex vivo control. Slides were processed using routine procedures for May-Grünwald-Giemsa (MGG), for Periodic Acid Schiff (PAS) after 5 min fixation in Carnoy (60\% ethanol, 30\% chloroform, 10\% acetic acid) and for Alcian blue staining. Alkaline phosphatase activity was assessed using Fast Red substrate and chromogene (Thermo Scientific, Illkirch, France) staining for $9 \mathrm{~min}$ at room temperature.

\subsection{Immunofluorescent staining}

Subconfluent layers of CLEC213 cells were prepared in 24-well plates containing glass coverslips. For epithelial marker staining, cells were washed twice with PBS, fixed for $15 \mathrm{~min}$ in $4 \%$ paraformaldehyde, and finally permeabilized with PBS containing $0.5 \%$ Triton X100. E-cadherin staining was performed with a specific monoclonal antibody (Biosciences, clone $36 \mathrm{BD}$ ) diluted 1:50 in PBS with $2 \%$ bovine serum albumin (BSA), 0.1\% Triton X100. Pan-cytokeratin staining was performed with a monoclonal antibody cocktail (Sigma, clones C-11, PCK-26, CY-90, KS-1A3, M20, A53-B/A2) diluted 1:50 in the same buffer as above. Fluorescent antigen expression was revealed by staining for $1 \mathrm{~h}$ with an Alexa ${ }^{\circledR} 488$-coupled secondary goat anti-mouse $\operatorname{IgG}(\mathrm{H}+\mathrm{L})$ antibody (Invitrogen) diluted 1:2000 in the same buffer. Nuclei were counter-stained with Vectashield H-1000 DAPI (Vector S1024).

To reveal influenza virus replication and viral antigen expression after CLEC213 infection, cells were washed twice in serum-free DMEM, then infected at an M.O.I. of 0.1 PFU/cell for H5N9, H1N1 and H6N2 and at an M.O.I. of 0.01 for H9N9 by incubating monolayers
$1 \mathrm{~h}$ at $37^{\circ} \mathrm{C}$ with $300 \mu \mathrm{L}$ of virus dilutions prepared in serumfree DMEM (1\% PS). After virus adsorption, $700 \mu \mathrm{L}$ of the same medium supplemented with $1 \mu \mathrm{g} / \mathrm{mL}$ of TPCK trypsine $(t=0)$ were added to each well. At $4 \mathrm{~h}$ post-infection, cells were washed, fixed and permeabilized. Influenza virus antigen NS1 was revealed with an anti-NS1 mouse monoclonal antibody diluted at 1:800 and a secondary goat anti-mouse antibody conjugated to Alexa 488, as described above. The monoclonal antibody used recognized both alleles of NS1. Fluorescence imaging was done using an AxioVision REL 4.6 (ZEISS) Digital Image System.

\subsection{Electron microscopy}

CLEC213 adherent cells were cultured to sub-confluence in Petri dishes (100 $\mathrm{mm}$ in diameter) and fixed with $2 \%$ glutaraldehyde in cacodylate buffer $(0.1 \mathrm{M}, \mathrm{pH} 7.4)$. After postfixation in $2 \%$ osmium tetroxide in cacodylate buffer at room temperature, the samples were dehydrated in ethanol dilutions and included in Epon. Ultrathin sections of $70 \mathrm{~nm}$ were placed on copper grid, stained with uranyl acetate and lead citrate, and examined under a CM10 Philips electron microscope.

\subsection{MHC typing}

The genotype at the MHC locus has been determined at three different passages of the cell culture (cell passages 30,91, 141). The MHC locus was genotyped using markers LEI0258 and GAB0001, both located in the B region of this locus. Marker LEI0258 has previously been described (McConnell et al., 1999), while GAB0001 was developed from a repeated region in an intron of B-DMA gene (Chazara et al., submitted for publication). A duplex PCR was performed on the DNA samples, with the forward primer of each marker fluorescently labelled on its 5' end (with HEX for LEI0258 and FAM for GABI0001). The sequences of the primers are given in Table 1. PCR amplifications were done in a volume of $10 \mu \mathrm{L}$ with $100 \mathrm{ng}$ of DNA, 1X of QIAGEN Multiplex PCR Kit and primer concentrations of $0.1 \mu \mathrm{M}$ with the following conditions: $94^{\circ} \mathrm{C}$ for $15 \mathrm{~min}$, then 35 cycles at $94^{\circ} \mathrm{C}$ for $45 \mathrm{~s}, 60^{\circ} \mathrm{C}$ for $1 \mathrm{~min} 30 \mathrm{~s}, 72^{\circ} \mathrm{C}$ for $1 \mathrm{~min}$, with a final extension at $72{ }^{\circ} \mathrm{C}$ for $15 \mathrm{~min}$. After a $1: 20$ dilution, the PCR products were loaded on an Applied 3730XL automated sequencer and the results were analysed using Genemapper v3.7. The allele sizes were compared with the data published by Fulton et al. (2006) and with results previously obtained on serologically defined samples. The LEI0258 and GAB0001 alleles were also sequenced, in order to characterize their detailed structures and flanking polymorphisms (indels and SNPs) that are useful to dis- 


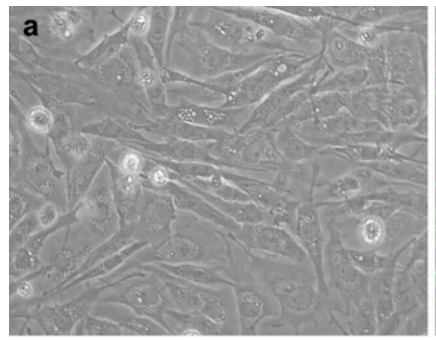

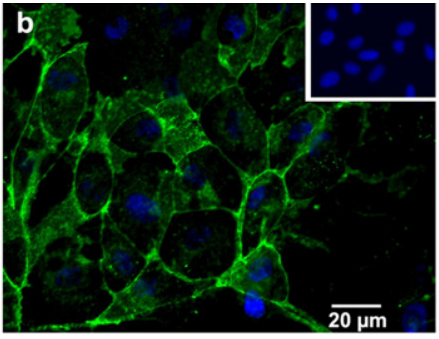

E-cadherin

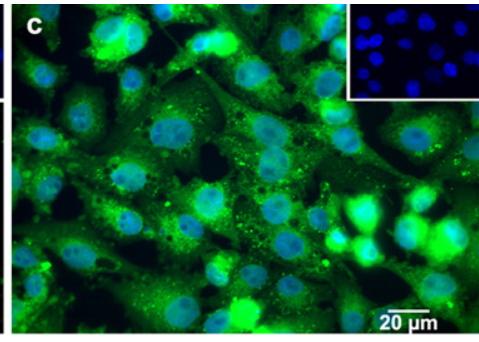

Pan-cytokeratin

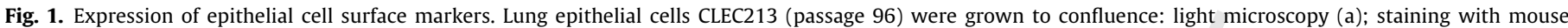

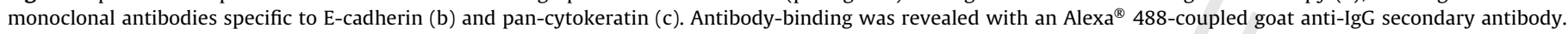
Negative controls with secondary antibody only were shown in the upper right corner. Nuclei were stained with Vectashield H.1000 DAPI.

criminate different alleles. Two PCRs using the unlabeled LEI0258 and GAB0001 primers, respectively, were also conducted in the same conditions, and the PCR products were directly sequenced from both ends. Sequences were aligned to references for comparison using BioEdit (Hall, 1999).

\subsection{Expression of collectins and TLR $m R N A$}

Total RNA was extracted from lung tissue and CLEC213 cell culture with Tri Reagent ${ }^{\circledR}$ solution following the manufacturer's recommendations (Sigma-Aldrich), and then subjected to an RNAse-free DNAse I treatment (Invitrogen) to remove contaminat- ing DNA. The reverse transcription reaction was performed with $1 \mu \mathrm{g}$ of RNA with Superscript ${ }^{\mathrm{TM}}$ First-Strand Synthesis System for RT-PCR (Invitrogen) following the manufacturer's indications. PCR analyses were conducted to assess the expression of chicken collectin genes (Hogenkamp et al., 2006), as well as the expression of chicken TLR3 and TLR4 genes using specific primers (Table 1 ).

\subsection{Virus growth curve}

Subconfluent CLEC213 monolayers (F25) were infected with H6N2 virus at an M.O.I. of 0.001 PFU/cell by incubating $2 \mathrm{~mL}$ of a virus dilution prepared in serum-free DMEM ( $1 \% \mathrm{PS})$ for $1 \mathrm{~h}$ at $37^{\circ} \mathrm{C}$.

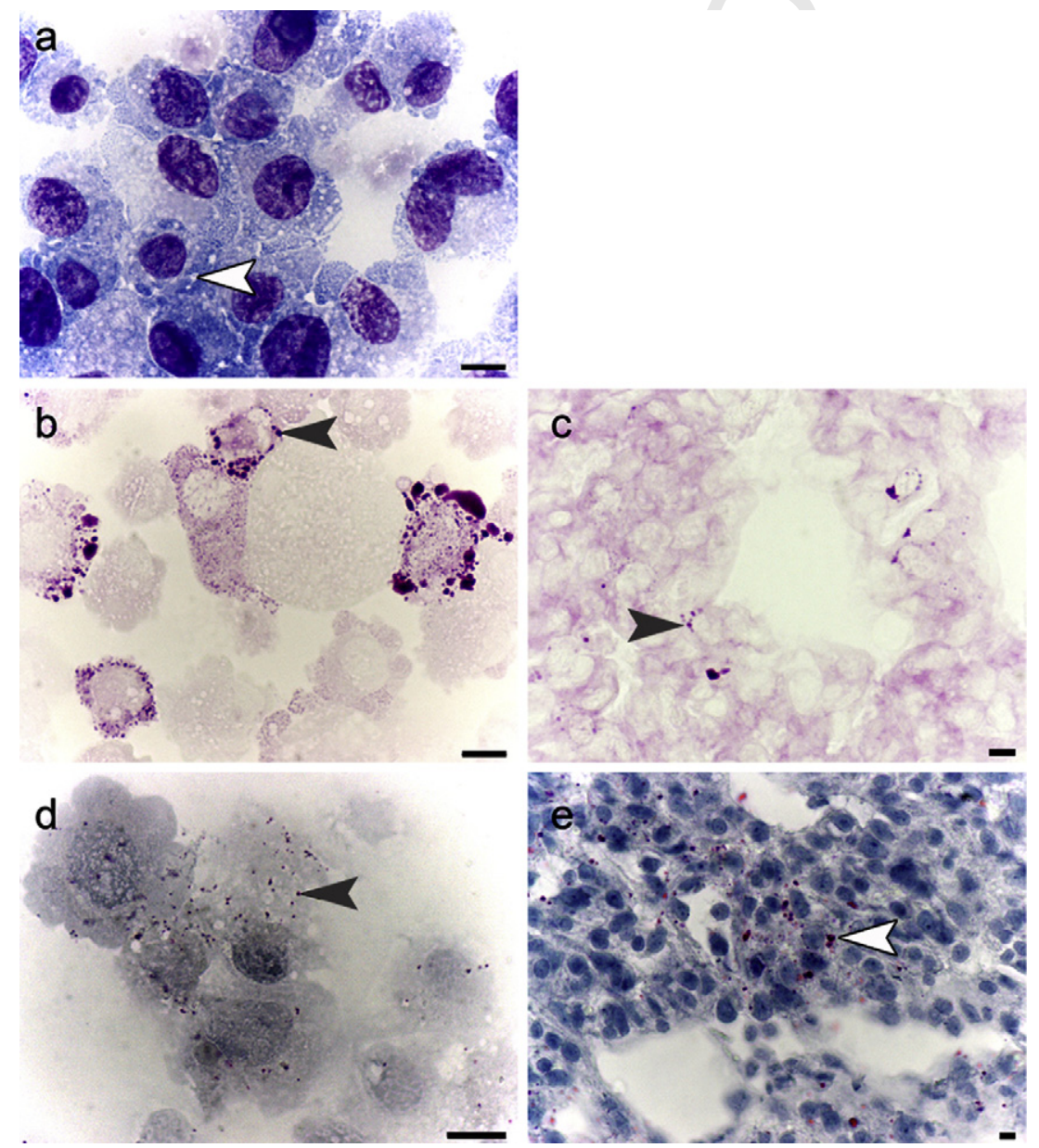

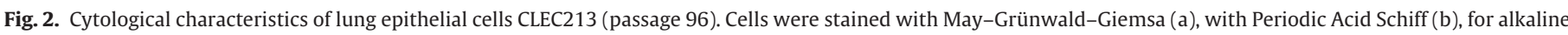

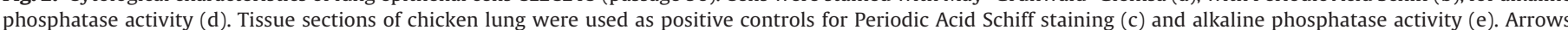
indicate the localisation of staining. Scale bar $=20 \mu \mathrm{m}$. 

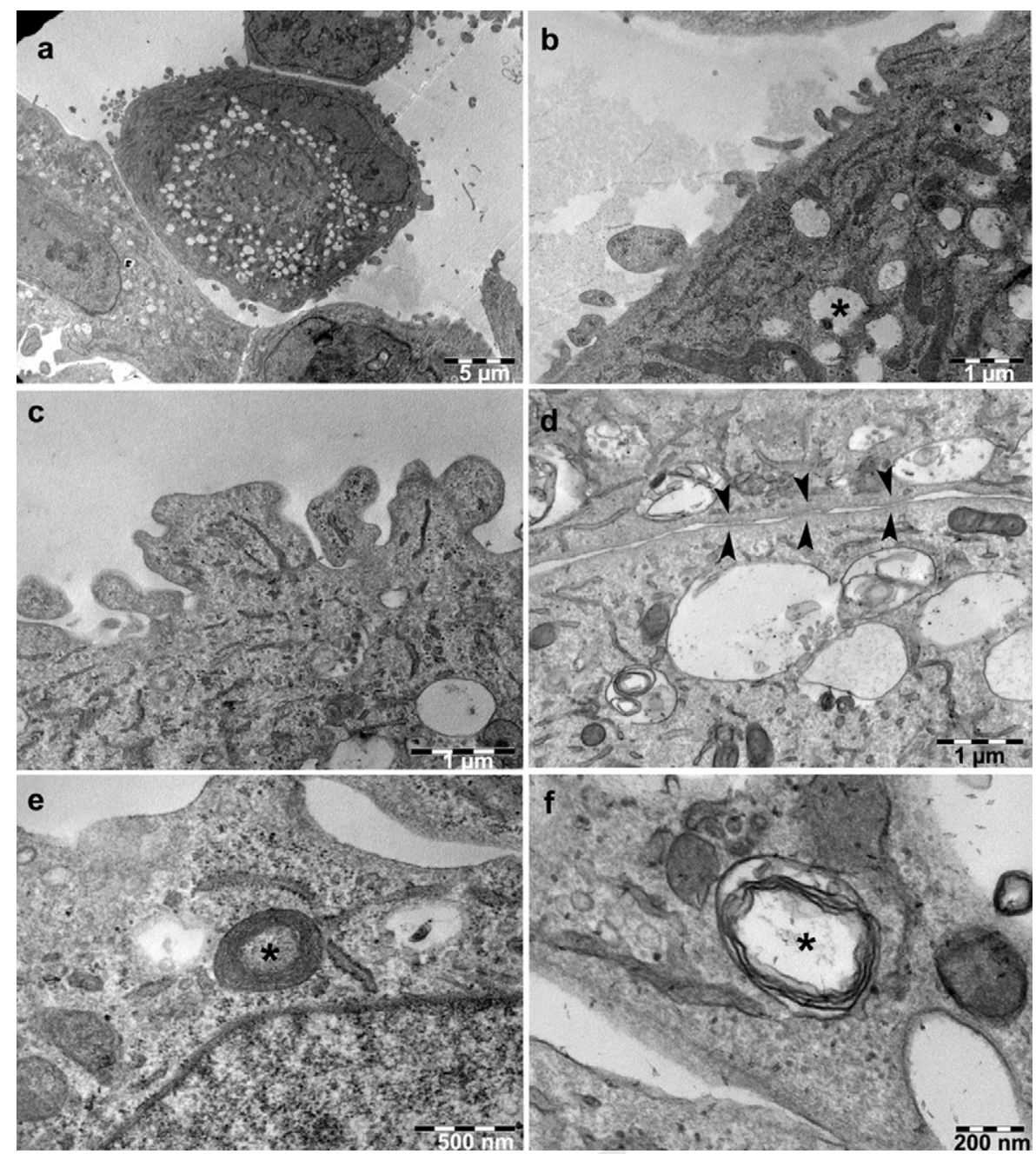

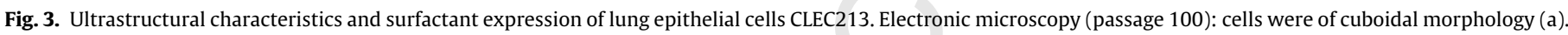

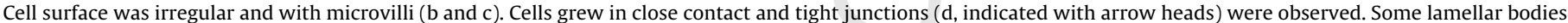
were identified (e and f, indicated with asterisks).

After virus adsorption, $10 \mathrm{~mL}$ of serum-free DMEM (1\% PS) was added in each flask. Unless otherwise stated, TPCK-treated trypsin $(0.4 \mu \mathrm{g} / \mathrm{mL}$ final $)$ was added to the medium. MDCK cells were used in parallel as a control in the presence of trypsin $(1 \mu \mathrm{g} / \mathrm{mL}$ final $)$. The kinetics of viral production was measured in supernatants from 12 to $48 \mathrm{~h}$ post inoculation through titration on MDCK. Viral titers are expressed as PFU/mL.

\subsection{Quantification of cellular cytokine mRNAs}

Subconfluent monolayers of CLEC213 cells were prepared in six-well culture plates $\left(10^{6}\right.$ cells per well). In order to evaluate their response to TLR agonists, cells were stimulated for 4 and $24 \mathrm{~h}$ with LPS $(10 \mu \mathrm{g}$ per $\mathrm{mL}$ final) or poly I:C (50 $\mu$ g per $\mathrm{mL}$ final) in DMEM (10\% FCS, 1\% PS). Untreated cultured cells served as negative controls. To test the immune response to avian influenza virus infection, cells were washed twice in serum-free DMEM, then infected at an M.O.I. of $1 \mathrm{PFU} /$ cell by incubating the monolayers for $1 \mathrm{~h}$ at $37^{\circ} \mathrm{C}$ with $500 \mu \mathrm{L}$ of a virus dilution prepared in serumfree DMEM (with $1 \%$ of penicillin and streptomycin). After virus adsorption, $1 \mathrm{~mL}$ of DMEM (10\% FBS, 1\% PS) was added to each well. Negative controls were prepared from cells stimulated with sterile allantoic fluid in the same conditions. At $4 \mathrm{~h}$ post-infection, cells were harvested.
Total RNA was extracted from cells with Tri Reagent ${ }^{\circledR}$ solution as described above. The reverse transcription reaction was performed with $1 \mu \mathrm{g}$ of RNA with Superscript ${ }^{\mathrm{TM}}$ First-Strand Synthesis System for RT-PCR (Invitrogen), using an oligo-dT primer. Specific cDNAs in samples (dilution 1:10) were quantified in triplicate by fluorimetric real-time PCR (Chromo $4^{\mathrm{TM}}$, Bio-Rad). Ten-fold serial dilutions of a standard plasmid containing either chicken cytokine or chemokine or GAPDH cDNA were used to produce a standard curve from $10^{0}$ to $10^{6}$ copy numbers for each target cDNA. The reaction mixture (15 $\mu \mathrm{L}$ in iQ Supermix SYBR Green, Bio-Rad) contained $2 \mu \mathrm{L}$ of the cDNA sample or a known concentration of standard plasmid, and 7.5 picomoles of each specific primer pair. The list of primers for IL6 , TGF- $\beta 4$, IFN- $\alpha$, IFN- $\beta$, IL-1 $\beta$, LITAF, IL-8 (CXCLi2), CCL5 (RANTES), CCL4 (MIP-1 $\beta$ ) and GAPDH is given in Table 1.

The PCR conditions were as follows: initial denaturation at $95^{\circ} \mathrm{C}$ for $5 \mathrm{~min}, 40$ cycles consisting each of $10 \mathrm{~s}$ at $95^{\circ} \mathrm{C}, 10 \mathrm{~s}$ at annealing temperature. Standard curves were obtained by plotting crossing cycle number (threshold or crossing point) as a function of log plasmid DNA concentration for each target sequence. The linear regression obtained was characterized by its slope $(-1 / \log$ : efficiency of amplification), $y$-intercept, mean squared error and regression coefficient. The concentration of target cDNA in a sample was deduced from the crossing point obtained and from the corresponding standard curve, and finally normalized to $10^{4}$ copy number of GAPDH cDNA in the same sample. As an assessment 
of specificity, melting curves were obtained for each PCR product by performing a progressive final denaturation, raising the temperature to $95^{\circ} \mathrm{C}$ at a transition rate of $0.5^{\circ} \mathrm{C} / \mathrm{s}$ with fluorescence measurement every second. Only PCR products showing a unique temperature of fusion which confirms a unique PCR product were retained for further quantitative automated analysis with the Opticon Monitor 3 software (Bio-Rad).

\section{Results}

\subsection{Lung cell characterization}

The CLEC213 cells were derived from a lung explant of a 5 weekold chicken and were maintained in culture for more than 140 passages without apparent changes in their phenotype. CLEC213 cells grew as a monolayer and after 96 passages they were checked for the expression of several epithelial markers. They scored positive with a pan cyto-keratin antibody and expressed E-cadherin at the cell surface (Fig. 1), but not vimentin (data not shown). On cytological preparations, cells were cohesive, heterogeneous in size ranging from 20 to $60 \mu \mathrm{m}$ diameter and exhibited polyhedral morphology. Their abundant cytoplasm contained numerous small vacuoles, $2-5 \mu \mathrm{m}$ in size, which remained optically empty after MGG staining (Fig. 2). An alkaline phosphatase activity was detected in the cytoplasm of all cells, similar to what is observed in a variety of cells of the lung parenchyma, including cells lining atria and air capillaries, and endothelial cells lining blood capillaries. Specific chemical staining procedures were performed in order to identify the vacuolar content. Vacuoles in CLEC213 cells were strongly stained with Periodic Acid Schiff, like the mucous cells lining atria and bronchi as well as granular cells of the lung parenchyma. This is indicative for a polysaccharidic or mucopolysaccharidic content (Fig. 2). However, the vacuolar content was negative for alcian blue staining as were granular cells of lung parenchyma. It is worthwhile to note that in control histological slides of the chicken lung, some chicken epithelial cells lining the bronchi were positive for this staining as is described for mammalian mucous cells (data not shown).

Ultrastructural observation of the CLEC213 cells was performed after 100 passages. The cells appeared in close contact forming sheets of cuboidal cells (Fig. 3a). The cell surface was irregular with the presence of short microvilli (Fig. $3 b$ and c). The cell membrane exhibited some degree of specialization with foci of close contact between adjacent cells reminiscent of junctional complexes (Fig. 3d). The cytoplasm contained numerous membrane-bound vacuoles. Some of them were filled with lamellar material resembling the typical lipid bilayer lamellar shape of the lamellar bodies (Fig. 3d-f).

Expression of chicken surfactant genes such as cLL and cSPA could be detected by RT-PCR in extracts of CLEC213 cells after more than 100 passages as well as in extracts from chicken lung tissue (Fig. 4b). As expected, these markers were not expressed in DF1 (chicken fibroblasts), nor LMH (chicken hepatocytes) that were both used as controls.

\subsection{MHC typing}

The MHC phenotyping gave similar results for all three CLEC213 culture passages tested. The allele sizes obtained were $357 \mathrm{bp}$ for the marker LEI0258 and 173 bp for GAB0001 and identical to allelic sizes of B21 reference samples for the same markers (Fulton et al., 2006; Chazara et al., submitted for publication). Furthermore, the sequences of these alleles were identical to the sequences obtained for white leghorn chicken reference samples serologically defined as B21.
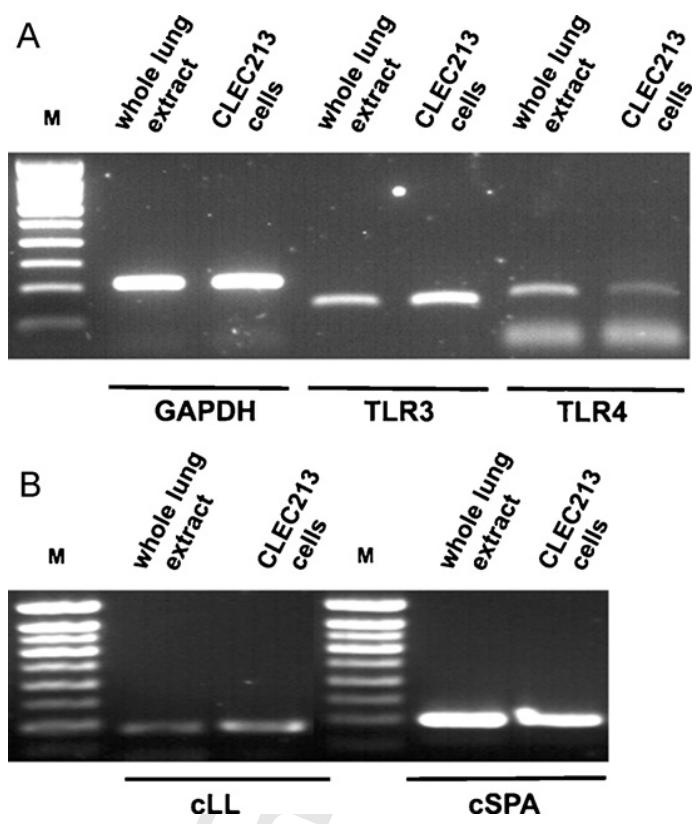

Fig. 4. Gene expression of TLR3 and TLR4 (a) and of surfactant proteins (cLL and cSPA) (b) was detected at the mRNA level (passage 140). Positive control was whole lung extract.

\subsection{Functional response to TLR agonists}

Mammalian epithelial cells can express several TLRs enabling them to respond to different types of pathogens. We checked the chicken lung epithelial cells for activation of TLR genes. Like whole lung extract, CLEC213 cells expressed constitutive levels of mRNA for TLR4 and TLR3 after 100 passages (Fig. 4a). In contrast, chicken DF1 fibroblasts used as control expressed barely detectable level of both TLR mRNAs. In addition, CLEC213 clearly responded to TLR agonists (Fig. 5). In absence of stimulation, no transcription was observed for IFN- $\alpha$, IFN- $\beta$ and IL- 8 genes. Stimulation with LPS $(10 \mu \mathrm{g} / \mathrm{mL})$ induced IFN- $\alpha$ gene expression after $4 \mathrm{~h}$ (with median value of $10^{2}$ copies per $10^{4}$ copies of GAPDH as reference) which levelled off at $24 \mathrm{~h}$. Expression of the IFN- $\beta$ gene was higher than for IFN- $\alpha$, with an increase up to $10^{4}$ copies $4 \mathrm{~h}$ after stimulation, and a subsequent decrease to $10^{2}$ copies $24 \mathrm{~h}$ later. Expression of IL- 8 gene was highly elevated $4 \mathrm{~h}$ after stimulation (up to $10^{5}$ copies) and remained up to $10^{4} 24 \mathrm{~h}$ after stimulation. The gene expression response to poly (I:C) $(50 \mu \mathrm{g} / \mathrm{mL})$, however, showed a different pattern. Expression of the IFN- $\alpha$ gene increased after 4 and $24 \mathrm{~h}$ after stimulation, up to $10^{2}-10^{3}$ copies. Expression of the IFN- $\beta$ gene was elevated only after $24 \mathrm{~h}$ of stimulation (up to $10^{3}$ copies). Expression of the IL-8 gene was diminished compared to LPS stimulation and a higher response (up to $10^{4}$ copy number) $24 \mathrm{~h}$ after stimulation compared to $4 \mathrm{~h}$ after stimulation.

\subsection{Replication and immune response to low pathogenic avian influenza viruses}

To check the cell permissivity to low pathogenic avian influenza viruses, CLEC213 cells were mock-infected, or infected with a panel of virus subtypes: H1N1, H5N9, H6N2 (M.O.I. of $0.1 \mathrm{PFU} /$ cell) or H9N9 (M.O.I. of $0.01 \mathrm{PFU} / \mathrm{cell}$ ) in the presence of trypsin in the culture media. After $4 \mathrm{~h}$ of incubation, the presence of influenza virus non structural protein (NS1) antigen was revealed by immunofluorescence using a monoclonal antibody directed against NS1 (Fig. 6). A large fraction of cells (depending on the M.O.I.) was specifically stained demonstrating the replication of all the influenza viruses tested. In addition, to test whether CLEC213 were able to support 
IFN-alpha

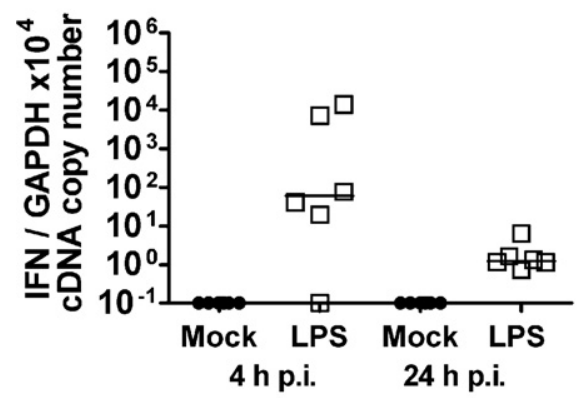

IFN-beta
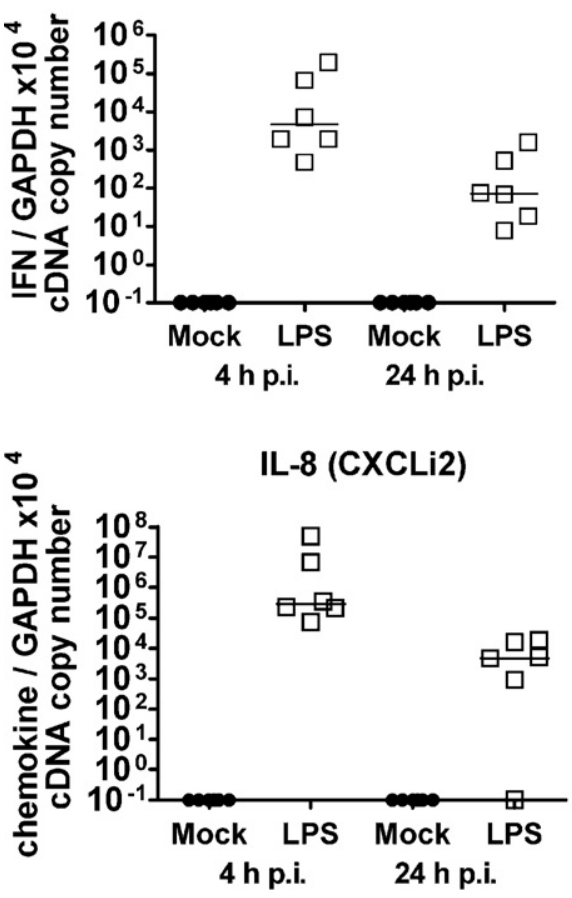

IFN-alpha

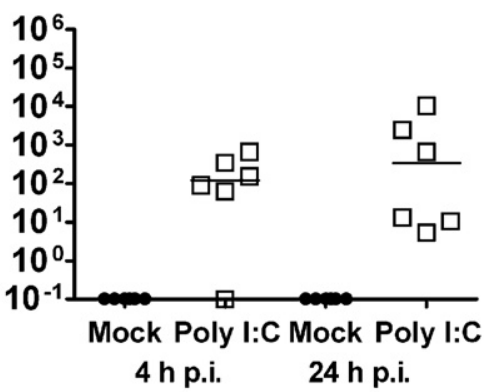

IFN-beta

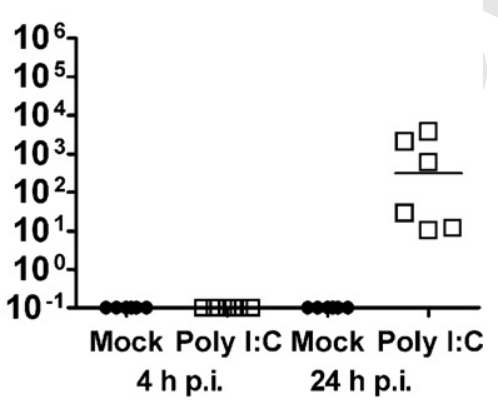

IL-8 (CXCLi2)

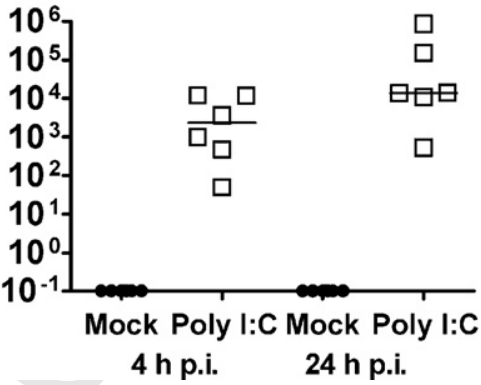

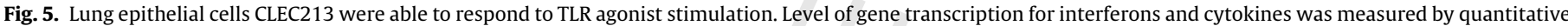

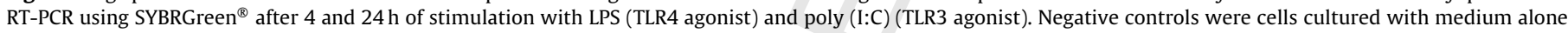

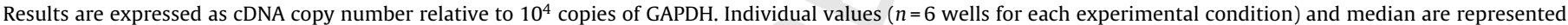
Arbitrary value of 0.1 copy is given when no transcription is detected.

viral replication in multiples cycles, the viral growth kinetics of the H6N2 subtype were measured in CLEC213, both in the presence and in the absence of trypsin $(0.4 \mu \mathrm{g} / \mathrm{mL}$ final concentration, as CLEC213 did not withstand the contact of trypsin-supplementation as well as MDCK). As a positive control, MDCK cells were infected in parallel at the same M.O.I. in the presence of trypsin $(1 \mu \mathrm{g} / \mathrm{mL}$ final $)$. The virus titer in culture supernatant of MDCK reached a plateau $48 \mathrm{~h}$ post-infection, with a maximum of $10^{6} \mathrm{PFU} / \mathrm{mL}$. In the presence of trypsin, CLEC213 supported efficient viral growth with a maximum extracellular titer of $10^{5} \mathrm{PFU} / \mathrm{mL}$ at $12 \mathrm{~h}$ post-infection which was 10 times more than for MDCK at the same time point. After $24 \mathrm{~h}$ of culture, the cell monolayer became disintegrated. Without supplementation of trypsin, CLEC213 were still able to support virus growth beyond this time point. However, the maximum titer was about one 100-fold less than in the presence of trypsin.

For analysis of the immune response, CLEC213 cells were infected with the H6N2 isolate. Cells treated with sterile allantoic fluid added in the same proportion as for viral infection in vitro served as control. Four hours post infection, infected cells maintained confluence and the number of intracellular copies of viral RNA coding for the influenza M-protein was measured by qRT-
PCR (Ward et al., 2004). Infected cell samples reached a high level of $10^{5-6}$ copies per $\mu \mathrm{g}$ of RNA (Fig. 7). The level of cytokine and chemokine gene expression remained below the detection level in controls. H6N2 induced a very high expression of IFN- $\alpha$ (up to $10^{7}$ copies per $10^{4}$ GAPDH copies as reference) (Fig. 6), but no IFN- $\beta$ at the time tested (not shown). H6N2 also induced elevated gene expression of IL-8 (up to $10^{4}$ copies). In addition, markedly elevated gene expression level was observed for TGF- $\beta 4$, and a lower expression level for LITAF (TNF pathway) and the chemokine CCL5 (up to $10^{2}$ copies). Expression of IL-1 $\beta$ and CCL4 gene was slightly induced by the viral infection (Fig. 8).

\section{Discussion}

Respiratory epithelia are essential cellular compartments participating in the defence against influenza viruses and in particular in inducing a protective or in some cases detrimental immune/inflammatory response, and thus complementary to the function of alveolar macrophages in mammals (Chan et al., 2005; Deng et al., 2008; Peiris et al., 2009). It is not yet known whether avian respiratory epithelia are crucially involved in the initiation of 

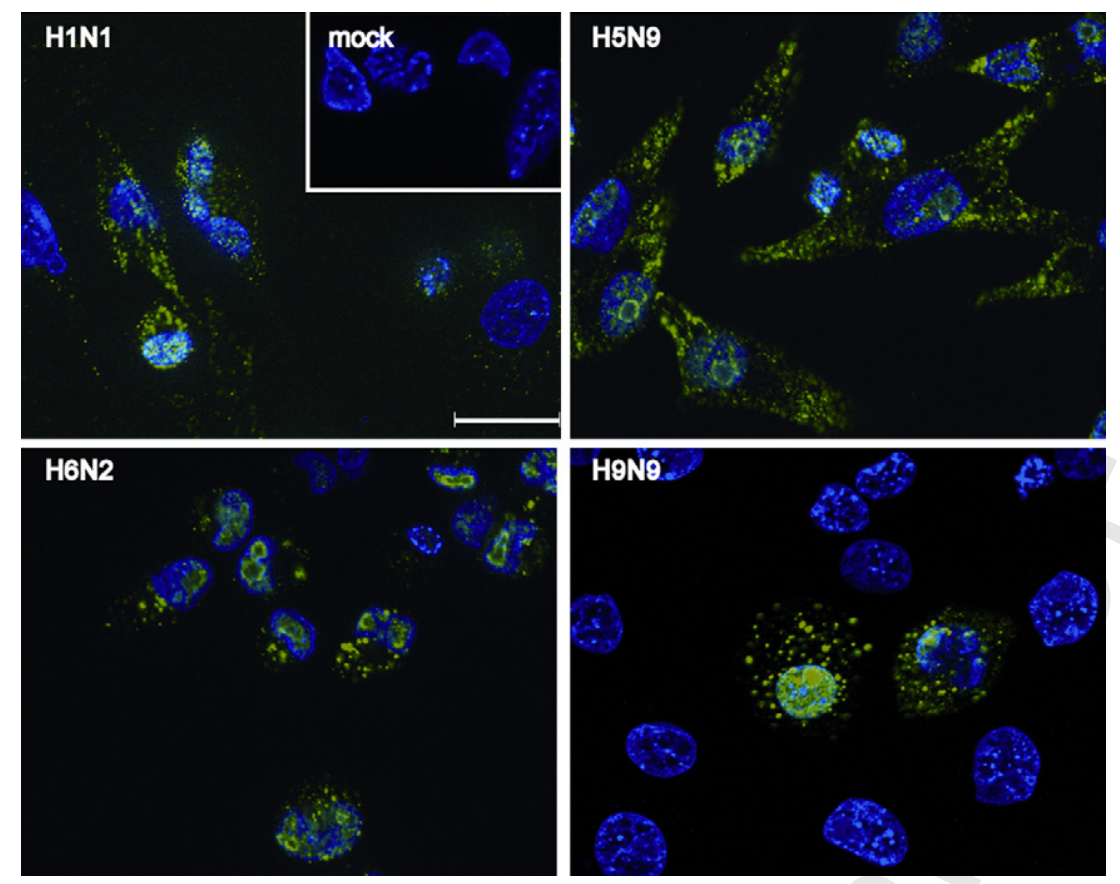

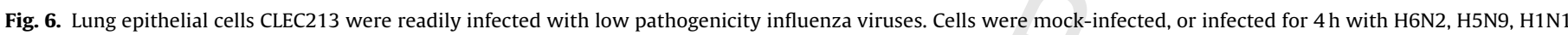

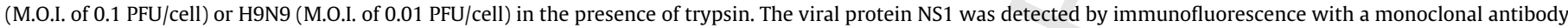
obtained in the laboratory.

the immune response in a way similar to what is observed in mammals. Avian influenza viruses in the chicken initially replicates in the upper part of the respiratory tract, notably in the trachea, but replication also takes place in the lungs, depending on the viral strain and/or the route of inoculation (Daviet et al., 2009; Munier et al., 2010; Reemers et al., 2009b, 2010). To extend the knowledge on the lung defence mechanisms, we focused our efforts to examine the characteristics of the chicken lung epithelium as a possible actor involved in the lung immune response. We were successful in obtaining epithelial cells from lung explants of white leghorn chickens. Their epithelial origin was demonstrated by their formation of a cohesive cell monolayer, their membrane specialization and their labelling with anti-E-cadherin and anti-cytokeratin. After numerous attempts of long-term culture, we finally derived a cell line, CLEC213, which maintained these epithelial characteristics. These cells exhibited a polyhedral form in culture with a large diameter of $20-60 \mu \mathrm{m}$ and a central ovoid nucleus. They were not of a fibroblast origin since they did not score positive for anti-vimentin antibodies and they displayed several features of mammalian type II pneumocytes. They were characterized as carrying the B21 MHC haplotype.

The presence of pneumocyte II-like cells can be assumed in birds since cuboid granular cells with numerous lamellar bodies similar to what is observed in mammalian type II pneumocytes are present in the atria of bird lung airways (Scheuermann et al., 1997). These cells are polarized, form junctional complexes between them and exhibit microvilli at the apical cell surface. They are found scattered among atrial squamous cells. Similar squamous cells, which are also called respiratory cells, constitute the walls of air capillaries. This second cell type does not seem to have a real counterpart in mammals, in that it is able to produce a trilamellar substance covering the atrial walls when mixed with the lung surfactant, which is probably derived from the granular cells and their lamellar bodies (Klika et al., 1999; Scheuermann et al., 2000).

Alkaline phosphatase activity was detected in CLEC213 as well as in histological sections of chicken lung parenchyma. Although this enzyme is found in mammalian type II pneumocytes (Edelson et al., 1988), it is not specific for that cell type, as it can also be detected in macrophages and endothelial cells (Muruganandam et al., 1997; Tatrai et al., 2006).

Lamellar bodies contained in membrane-bound vacuoles as in mammalian type II pneumocytes (Wang et al., 2007) were also identified in CLEC213 lung epithelial cells. However, they were far less numerous than those observed on histological sections of avian lung parenchyma (Cuesta et al., 2005; Scheuermann et al., 1997, 2000). In addition, expression of genes coding for chicken collectins cLL and cSPA, identified as analogs of lung surfactants proteins (Hogenkamp et al., 2006), was observed. This observation, in addition to the presence of vacuoles filled with polysaccharides, was in favour of a secretory activity of CLEC213.

In mammals, lung epithelial cells are able to detect pathogens through a range of receptors recognizing specific pathogens motifs (PAMPS) such as TLRs (Schleimer et al., 2007). TLRs have been identified in the chicken (Cormican et al., 2009). We confirmed that chicken CLEC213 lung epithelial cells expressed TLR3 and TLR4 under non-stimulated conditions. The cells did respond to LPS and to poly (I:C), which are known agonists of TLR4 and TLR3, respectively, suggesting that these receptors are functional in CLEC213. The response was characterized by a substantial IFN- $\alpha$ gene expression elevation, that was more prolonged after poly (I:C) stimulation than after LPS stimulation, while the opposite was observed for the IFN- $\beta$ gene transcription. With respect to the chemokine response, expression of IL-8 was pronounced after stimulation with both agonists. However, activation of other genes such as CCL5 and CCL4 remained low in all conditions tested. Altogether, the cytokine expression pattern was in good agreement with what is observed in mammalian lung epithelia (Gribar et al., 2008).

CLEC213 cells were found to be permissive to all the avian low pathogenic influenza viruses tested (H5N9, H1N1, H6N2, H9N9), as demonstrated by the presence of the viral NS1 protein evidencing productive viral replication as soon as $4 \mathrm{~h}$ post-infection. The distribution of the NS1 protein, a major viral antagonist of the cellular antiviral response (Hale et al., 2010), was analogous to what was observed when mammalian MDCK cells were infected with the 


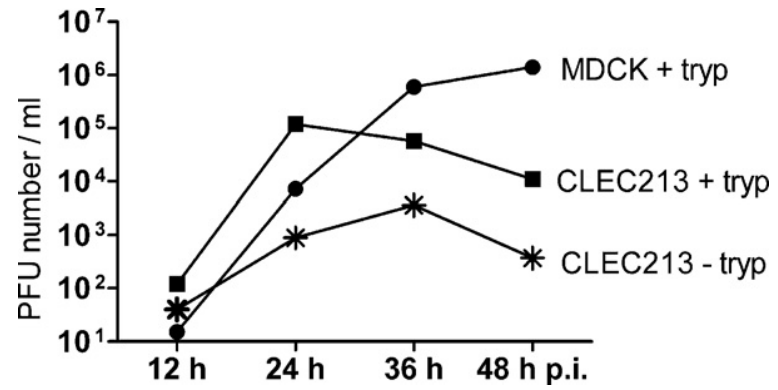

Fig. 7. Growth curve of H6N2 on CLEC213 and MDCK. Confluent monolayers (F25) were inoculated at an M.O.I. of 0.001. At the indicated time points, infectious particles in the media were titrated through plaque assay in MDCK. $\left({ }^{*}\right)$ CLEC213 without added trypsin; (•) CLEC213 with trypsin $(0.4 \mu \mathrm{g} / \mathrm{mL}$ final); ( $\mathbf{\square})$ MDCK with added trypsin $(1 \mu \mathrm{g} / \mathrm{mL}$ final).

same viruses. In addition CLEC213 supported the growth of avian influenza virus (H6N2) even in the absence of trypsin, albeit to lower levels. However, in the presence of trypsin, viral endpoint titers achieved with CLEC213 were diminished when compared with MDCK. Therefore, CLEC213 appear more useful for immunological and cell biological studies than for AIV amplification or live cycle analyses.

The final aim of our study was to check the specific response to influenza viruses. H6N2, isolated from duck and exhibiting no pathogenicity for chickens (Dr. V. Jestin, personal communication), was studied as an example. Infection with the H6N2 efficiently activated the IFN- $\alpha$ gene expression $4 \mathrm{~h}$ post-infection, but expression of the IFN- $\beta$ gene could not be evidenced, contrary to what is observed in mammalian cells. This is in agreement with what was described chicken fibroblasts (Barber et al., 2010), thus questioning the precise role of IFN- $\beta$ against viral infection in the avian system. Indeed the antiviral response of the chicken presents certain peculiarities, notably the fact that the chicken genome does not harbour an orthologue of RIG-I, a RNA virus sensor involved in the mammalian antiviral response to influenza (Barber et al., 2010). However, the chicken possesses TLR3 and thus has the capacity to detect viral dsRNA genomes or replication intermediates (Cormican et al., 2009). So far, little is known about the signalling pathways involved in the response to avian influenza viruses in the chicken. Recent studies on avian influenza and immune chicken responses are indeed difficult to interpret in terms of in vivo involvement of the IFN- $\beta$ response (Daviet et al., 2009; Munier et al., 2010; Reemers et al., 2009b). Chicken CLEC213 lung epithelial cells were also able to activate other genes of the innate immune response such as IL-1 $\beta$, LITAF (a member of the TNF- $\alpha$ activation pathway, Hong et al., 2006), as well as chemokines known to be important in the immune response to influenza in mammals, such as IL-8, CCL5 and CCL4 (Bernasconi et al., 2005; Cheng et al., 2010; Guillot et al., 2005). However, IL-6 expression was not detected, although this cytokine can be produced by mammalian lung epithelial cells after influenza infection (Cheng et al., 2010; Guillot et al., 2005). Nevertheless, IL-6 might be an important partner of the lung immune defence against influenza viruses in chickens since its transcription has been most of the time shown after in vivo infection (Munier et al., 2010; Reemers et al., 2009b, 2010). The same pattern of interferon and chemokine gene expression that we observed in H6N2-infected cells was also observed after infection with H5N9 (data not shown). By comparison, with the same

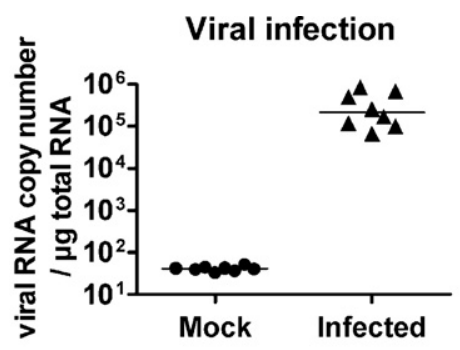

IL-1 beta
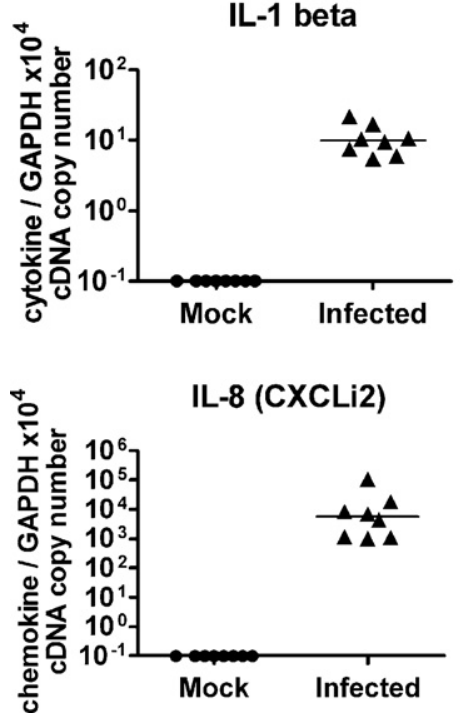

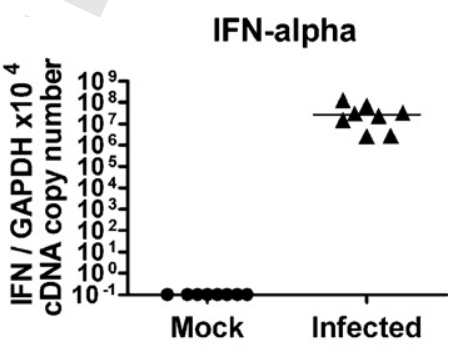

LITAF

TGF-beta 4

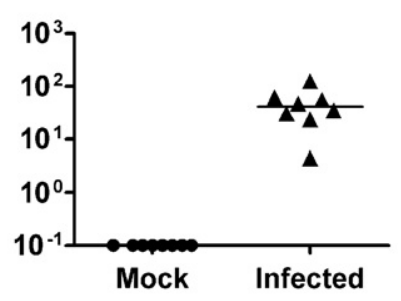

CCL5 (RANTES)

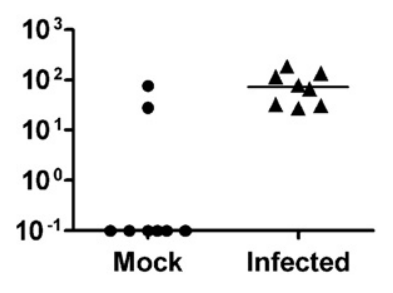

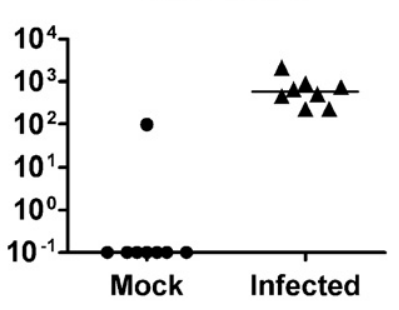

CCL4 (MIP-1 beta)

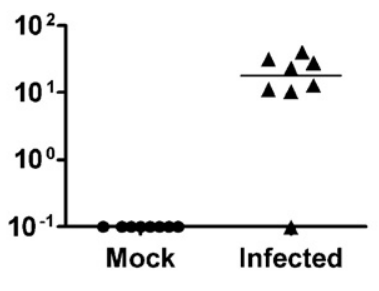

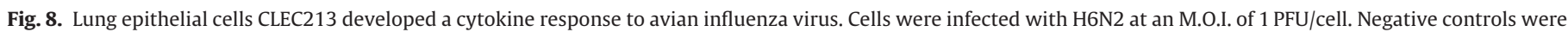

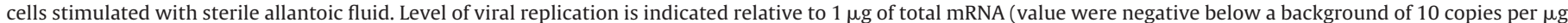

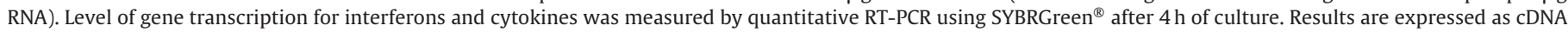

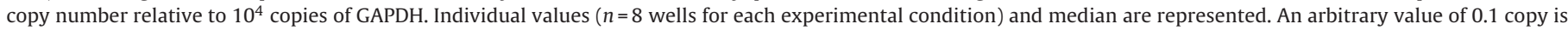
given when transcription is below detection level. 
culture conditions and at the same times after infection, we did not observe any response in chicken DF1 fibroblasts although they were as efficiently infected as the lung epithelial cells (data not shown).

Therefore, we postulate that lung epithelial cells infected with influenza viruses should be able to actively participate in the immune response by recruiting a variety of leukocytes in the lung as they do in mammals since we show here that they initiate the expression of a panel of chemokine genes in addition to the activation of genes from the IFN family and TNF pathway.

In conclusion, we succeeded in establishing a novel chicken lung epithelial cell line. Our data support the assumption that this line could originate from chicken atrial granular cells, a possible functional analogue to mammalian type II pneumocytes, as indicated by the presence of lamellar-like bodies and by the expression of chicken collectins. Moreover, CLEC213 are able to respond to TLR and avian influenza viruses with increased cytokine and chemokine expression. Our aim is now to dissect the response to avian influenza viruses of this chicken respiratory epithelial cell line in the context of natural absence of the viral nucleic acid RIG-I sensor.

\section{Acknowledgements}

We are grateful to Dr. Nathalie Chanteloup for lively and stimulating discussion, and to Dr. Sascha Trapp for reviewing the manuscript. This work was supported by INRA Young Team funding and a Grant from the French Federative Research Institute 136.

\section{References}

Abd El Rahman, S., El-Kenawy, A.A., Neumann, U., Herrler, G., Winter, C., 2009. Comparative analysis of the sialic acid binding activity and the tropism for the respiratory epithelium of four different strains of avian infectious bronchitis virus. Avian Pathol. 38 (1), 41-45.

Barber, M.R., Aldridge Jr., J.R., Webster, R.G., Magor, K.E., 2010. Association of RIG-I with innate immunity of ducks to influenza. Proc. Natl. Acad. Sci. U.S.A. 107 (13), 5913-5918.

Bauer, S., Muller, T., Hamm, S., 2009. Pattern recognition by Toll-like receptors. Adv. Exp. Med. Biol. 653, 15-34.

Bernasconi, D., Amici, C., La Frazia, S., Ianaro, A., Santoro, M.G., 2005. The IkappaB kinase is a key factor in triggering influenza A virus-induced inflammatory cytokine production in airway epithelial cells. J. Biol. Chem. 280 (25), 24127-24134.

Beug, H., von Kirchbach, A., Doderlein, G., Conscience, J.F., Graf, T., 1979. Chicken hematopoietic cells transformed by seven strains of defective avian leukemia viruses display three distinct phenotypes of differentiation. Cell 18 (2), 375-390.

Chan, M.C., Cheung, C.Y., Chui, W.H., Tsao, S.W., Nicholls, J.M., Chan, Y.O., Chan, R.W., Long, H.T., Poon, L.L., Guan, Y., Peiris, J.S., 2005. Proinflammatory cytokine responses induced by influenza A (H5N1) viruses in primary human alveolar and bronchial epithelial cells. Respir. Res. 6, 135.

Chaudhuri, N., Sabroe, I., 2008. Basic science of the innate immune system and the lung. Paediatr. Respir. Rev. 9 (4), 236-242.

Cheng, X., Xu, Q., Song, E., Yang, C.F., Kemble, G., Jin, H., 2010. The hemagglutinin protein of influenza A/Vietnam/1203/2004 (H5N1) contributes to hyperinduction of proinflammatory cytokines in human epithelial cells. Virology 406 (1), 28-36.

Cormican, P., Lloyd, A.T., Downing, T., Connell, S.J., Bradley, D., O’Farrelly, C., 2009. The avian Toll-like receptor pathway - subtle differences amidst general conformity. Dev. Comp. Immunol. 33 (9), 967-973.

Cuesta, N., Martinez, A., Cuttitta, F., Zudaire, E., 2005. Identification of adrenomedullin in avian type II pneumocytes: increased expression after exposure to air pollutants. J. Histochem. Cytochem. 53 (6), 773-780.

Daviet, S., Van Borm, S., Habyarimana, A., Ahanda, M.L., Morin, V., Oudin, A., Van Den Berg, T., Zoorob, R., 2009. Induction of Mx and PKR failed to protect chickens from H5N1 infection. Viral Immunol. 22 (6), 467-472.

Deng, R., Lu, M., Korteweg, C., Gao, Z., McNutt, M.A., Ye, J., Zhang, T., Gu, J., 2008. Distinctly different expression of cytokines and chemokines in the lungs of two H5N1 avian influenza patients. J. Pathol. 216 (3), 328-336.

Edelson, J.D., Shannon, J.M., Mason, R.J., 1988. Alkaline phosphatase: a marker of alveolar type II cell differentiation. Am. Rev. Respir. Dis. 138 (5), 1268-1275.

Gribar, S.C., Anand, R.J., Sodhi, C.P., Hackam, D.J., 2008. The role of epithelial Toll-like receptor signaling in the pathogenesis of intestinal inflammation. J. Leukoc. Biol. 83 (3), 493-498.

Guillot, L., Le Goffic, R., Bloch, S., Escriou, N., Akira, S., Chignard, M., Si-Tahar, M., 2005. Involvement of toll-like receptor 3 in the immune response of lung epithe- lial cells to double-stranded RNA and influenza A virus. J. Biol. Chem. 280 (7), 5571-5580.

Hale, B.G., Albrecht, R.A., Garcia-Sastre, A., 2010. Innate immune evasion strategies of influenza viruses. Future Microbiol. 5, 23-41.

Hall, T.A., 1999. BioEdit: a user-friendly biological sequence alignment editor and analysis program for windows 95/98/NT. Nucleic Acids Symp. Ser. 41, 95-98.

Henning, A., Schneider, M., Bur, M., Blank, F., Gehr, P., Lehr, C.M., 2008. Embryonic chicken trachea as a new in vitro model for the investigation of mucociliary particle clearance in the airways. AAPS PharmSciTech 9 (2), 521-527.

Himly, M., Foster, D.N., Bottoli, I., Iacovoni, J.S., Vogt, P.K., 1998. The DF-1 chicken fibroblast cell line: transformation induced by diverse oncogenes and cell death resulting from infection by avian leukosis viruses. Virology 248 (2), 295-304.

Hippenstiel, S., Opitz, B., Schmeck, B., Suttorp, N., 2006. Lung epithelium as a sentinel and effector system in pneumonia - molecular mechanisms of pathogen recognition and signal transduction. Respir. Res. 7, 97.

Hogenkamp, A., van Eijk, M., van Dijk, A., van Asten, A.J., Veldhuizen, E.J., Haagsman, H.P., 2006. Characterization and expression sites of newly identified chicken collectins. Mol. Immunol. 43 (10), 1604-1616.

Jeong, O.M., Kim, M.C., Kim, M.J., Kang, H.M., Kim, H.R., Kim, Y.J., Joh, S.J., Kwon, J.H., Lee, Y.J., 2009. Experimental infection of chickens, ducks and quails with the highly pathogenic H5N1 avian influenza virus. J. Vet. Sci. 10 (1), 53-60.

Kawaguchi, T., Nomura, K., Hirayama, Y., Kitagawa, T., 1987. Establishment and characterization of a chicken hepatocellular carcinoma cell line, LMH. Cancer Res. 47 (16), 4460-4464.

Klika, E., Scheuermann, D.W., De Groodt-Lasseel, M.H., Bazantova, I., Switka, A., 1998 An SEM and TEM study of the transition of the bronchus to the parabronchus in quail (Coturnix coturnix). Ann. Anat. 180 (4), 289-297.

Klika, E., Scheuermann, D.W., De Groodt-Lasseel, M.H., Bazantova, I., Switka, A., 1999 A scanning and transmission electron microscopy study of the parabronchia unit in quail (Coturnix coturnix) and town pigeons (Columba livia). Scanning 21 (4), 273-284.

Kong, B.W., Foster, L.K., Foster, D.N., 2007. Establishment of an immortal turkey turbinate cell line suitable for avian metapneumovirus propagation. Virus Res. 127 (1), 106-115.

Maina, J.N., 2002. Some recent advances on the study and understanding of the functional design of the avian lung: morphological and morphometric perspectives. Biol. Rev. Camb. Philos. Soc. 77 (1), 97-152.

Majo, N., Marti, M., O'Loan, C.J., Allan, G.M., Pages, A., Ramis, A., 1996. Ultrastructura study of turkey rhinotracheitis virus infection in turbinates of experimentally infected chickens. Vet. Microbiol. 52 (1-2), 37-48.

McConnell, S.K., Dawson, D.A., Wardle, A., Burke, T., 1999. The isolation and mapping of 19 tetranucleotide microsatellite markers in the chicken. Anim. Genet. 30 (3), 183-189.

Munier, S., Larcher, T., Cormier-Aline, F., Soubieux, D., Su, B., Guigand, L., Labrosse, B., Cherel, Y., Quere, P., Marc, D., Naffakh, N., 2010. A genetically engineered waterfowl influenza virus with a deletion in the stalk of the neuraminidase has increased virulence for chickens. J. Virol. 84 (2), 940-952.

Muruganandam, A., Herx, L.M., Monette, R., Durkin, J.P., Stanimirovic, D.B., 1997 Development of immortalized human cerebromicrovascular endothelial cell line as an in vitro model of the human blood-brain barrier. FASEB J. 11 (13) 1187-1197.

Neumann, G., Chen, H., Gao, G.F., Shu, Y., Kawaoka, Y., 2010. H5N1 influenza viruses: outbreaks and biological properties. Cell Res. 20 (1), 51-61.

Nganpiep, L.N., Maina, J.N., 2002. Composite cellular defence stratagem in the avian respiratory system: functional morphology of the free (surface) macrophages and specialized pulmonary epithelia. J. Anat. 200 (5), 499-516.

Peiris, J.S., Cheung, C.Y., Leung, C.Y., Nicholls, J.M., 2009. Innate immune responses to influenza A H5N1: friend or foe? Trends Immunol. 30 (12), 574-584.

Pillai, S.P., Lee, C.W., 2010. Species and age related differences in the type and distribution of influenza virus receptors in different tissues of chickens, ducks and turkeys. Virol. J. 7, 5.

Purcell, D.A., 1971. The ultrastructure of tracheal epithelium in the fowl. Res. Vet Sci. 12 (4), 327-329.

Reemers, S.S., Groot Koerkamp, M.J., Holstege, F.C., van Eden, W., Vervelde, L., 2009a. Cellular host transcriptional responses to influenza A virus in chicken tracheal organ cultures differ from responses in in vivo infected trachea. Vet. Immunol. Immunopathol. 132 (2-4), 91-100.

Reemers, S.S., van Haarlem, D.A., Groot Koerkamp, M.J., Vervelde, L., 2009b. Differential gene-expression and host-response profiles against avian influenza virus within the chicken lung due to anatomy and airflow. J. Gen. Virol. 90 (Part 9), 2134-2146.

Reemers, S.S., van Leenen, D., Koerkamp, M.J., van Haarlem, D., van de Haar, P., van Eden, W., Vervelde, L., 2010. Early host responses to avian influenza A virus are prolonged and enhanced at transcriptional level depending on maturation of the immune system. Mol. Immunol. 47 (9), 1675-1685.

Reese, S., Dalamani, G., Kaspers, B., 2006. The avian lung-associated immune system a review. Vet. Res. 37 (3), 311-324.

Scheuermann, D.W., Klika, E., De Groodt-Lasseel, M.H., Bazantova, I., Switka, A., 1997. An electron microscopic study of the parabronchial epithelium in the mature lung of four bird species. Anat. Rec. 249 (2), 213-225.

Scheuermann, D.W., Klika, E., De Groodt-Lasseel, M.H., Bazantova, I., Switka, A., 2000 Lamellar inclusions and trilaminar substance in the parabronchial epithelium of the quail (Coturnix coturnix). Ann. Anat. 182 (3), 221-233.

Schleimer, R.P., Kato, A., Kern, R., Kuperman, D., Avila, P.C., 2007. Epithelium: at the interface of innate and adaptive immune responses. J. Allergy Clin. Immunol. 120 (6), 1279-1284. 
Swayne, D.E., Slemons, R.D., 1994. Comparative pathology of a chicken-origin and two duck-origin influenza virus isolates in chickens: the effect of route of inoculation. Vet. Pathol. 31 (2), 237-245.

Tatrai, E., Brozik, M., Drahos, A., Kovacikova, Z., Six, E., Csik, M., Dam, A., 2006. The effect of stone-wool on rat lungs and on the primary culture of rat alveolar macrophages and type II pneumocytes. J. Appl. Toxicol. 26 (1), 1624.

Toth, T.E., 2000. Nonspecific cellular defense of the avian respiratory system: a review. Dev. Comp. Immunol. 24 (2-3), 121-139.

van der Goot, J.A., de Jong, M.C., Koch, G., Van Boven, M., 2003. Comparison of the transmission characteristics of low and high pathogenicity avian influenza A virus (H5N2). Epidemiol. Infect. 131 (2), 10031013.
Wang, D., Haviland, D.L., Burns, A.R., Zsigmond, E., Wetsel, R.A., 2007. A pure population of lung alveolar epithelial type II cells derived from human embryonic stem cells. Proc. Natl. Acad. Sci. U.S.A. 104 (11), 4449-4454.

Ward, C.L., Dempsey, M.H., Ring, C.J., Kempson, R.E., Zhang, L., Gor, D., Snowden, B.W., Tisdale, M., 2004. Design and performance testing of quantitative real time PCR assays for influenza A and B viral load measurement. J. Clin. Virol. 29 (3), 179-188.

Watson, R.R., Fu, Z., West, J.B., 2007. Morphometry of the extremely thin pulmonary blood-gas barrier in the chicken lung. Am. J. Physiol. Lung Cell. Mol. Physiol. 292 (3), L769-L777.

Zaffuto, K.M., Estevez, C.N., Afonso, C.L., 2008. Primary chicken tracheal cell culture system for the study of infection with avian respiratory viruses. Avian Pathol. 37 (1), 25-31. 